\title{
Biodiversity of nematodes biological indicators of soil quality in the agroecosystems
}

\author{
Biodiversidade de nematoides indicadores \\ biológicos da qualidade do solo em agroecossistemas
}

\author{
Gabriela Silva Moura1*, Gilmar Franzener ${ }^{1}$

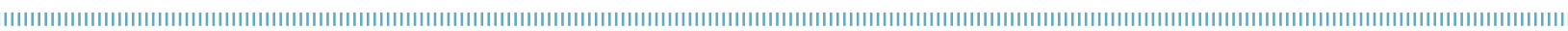

\begin{abstract}
Nematodes can be associated with the soil ecological condition, thus being associated with this sustainability condition of agricultural production. Studies of their diversity can be applied with the purpose of using them as bioindicators of environmental changes and the productive impacts. However, these organisms have been neglected in the agroecosystems, only assuming status of pathogen when their population is very high, with considerable losses in productivity. It is estimated that approximately $10 \%$ of the nematodes cause damage to plants, $25 \%$ are nematodes grouped into trophic levels of fungivores or fungal feeders, bacterivorous, and omnivores, according to the type of their food. In many cases it is not known the ratio of population level of the nematode with the level of damage in plants. For this reason, the use of pesticides and fertilizers is still part of the most common practices by farmers, causing loss of soil organic matter, soil erosion and groundwater contamination, in addition to an imbalance in the microbiote. The objective of this work was to make a brief review about the diversity of nematodes in the soil in the agroecosystems that can be used in studies of sustainability, as soil quality bioindicators. Several species of nematodes have the potential to be used as biological indicators of soil quality. In this sense, the knowledge and use of bioindicators by rural producers are important, in order to encourage practices of sustainable management systems that do not cause the soil biodiversity imbalance.
\end{abstract}

KEYWORDS: biological indicators; soil; agrobiodiversity.
RESUMO: Nematoides podem ser associados com a condição ecológica do solo, relacionando-se assim à condição de sustentabilidade da produçáo agrícola. Estudos da sua diversidade podem ser aplicados com a finalidade de utilizá-los como bioindicadores de alteraçôes ambientais e dos impactos produtivos, contudo esses organismos têm sido negligenciados nos agroecossistemas, somente assumindo status de patógeno quando sua população se encontra muito elevada, com acentuadas perdas em produtividade. Estima-se que aproximadamente $10 \%$ dos nematoides causam danos às plantas, $25 \%$ são nematoides agrupados nos níveis tróficos de fungívoros ou micófagos, bacterívoros e onívoros, de acordo com o tipo de sua alimentação. Em diversos casos não se conhece a relação do nível populacional do nematoide com o nível de dano nas plantas. Por esse motivo, o uso de pesticidas e fertilizantes é ainda uma prática comum por parte dos agricultores, ocasionando perda de matéria orgânica do solo, erosão e contaminação das águas subterrâneas, além de desequilíbrio na microbiota. O trabalho teve como objetivo fazer uma breve revisão sobre a diversidade de nematoides no solo em agroecossistemas que podem ser utilizados em estudos de sustentabilidade, como bioindicadores da qualidade do solo. Diversas espécies de nematoides apresentam potencial para serem utilizadas como indicadores biológicos da qualidade do solo. Nesse sentido, o conhecimento e o uso de bioindicadores pelos produtores rurais sáo importantes, no sentido de incentivar práticas de manejos sustentáveis que não ocasionem o desequilíbrio da biodiversidade do solo.

PALAVRAS-CHAVE: indicadores biológicos; solo; agrobiodiversidade. 


\section{INTRODUCTION}

Currently, it has been of great interest for researchers and farmers to evaluate the soil properties and know what are the effects of management practices on soil quality, since it is a matter that is directly related to the sustainability of the agroecosystems functions (SCHOENHOLTZ et al., 2000).

In comparison to many natural ecosystems, the agroecosystems receive numerous human actions that may cause serious fauna and flora disruption. Practices such as soil preparation and use of fungicides, insecticides, nematicides and herbicides can result in a decrease in soil microbial diversity (TIMPER, 2014).

Due to the great interest in studies on the soil quality, the edaphic fauna has been used as an indicator of this quality (ROVEDDER et al., 2004). To monitor and evaluate the soil changes, biological indicators of environmental quality have been utilized in the agroecosystems, due to their high sensitivity and ability to reflect the effects of soil management (BENINTENDE et al., 2008; KASCHUK et al., 2011).

Despite it is not recent, the discussion about the use of indicators has been gaining attention on what are the most effective parameters to assess the impact of the agricultural use of the soils. In practical terms, farmers use "empirical" indicators, such as the presence of certain plants, insects, worms, among others, in addition to the analysis of the soil chemical fertility, presence of erosion on the property, organic matter content in the soil and soil compaction (KARLEN et al., 2003). In the scientific community, in addition to these parameters, the microbial activity evaluations appear, such as the soil respiration and the use of carbon sources, as well as the size and diversity of macro and microorganisms (TURKISH; BLUME, 1999).

To understand the soil management in agroecosystems, the knowledge on the concept of soil quality is fundamental. According to WEIL; MAGDOFF (2004), the soil quality is its ability to work within the limits of the ecosystem to sustain biological productivity, maintain environmental quality and promote plant and animal health, which can be measured through valuable indicators of soil alterations, such as the invertebrate microorganisms, because they are sensitive to changes in the soil conditions (NAHMANI; LAVELLE, 2002).

Under this perspective, it is essential to choose a minimum set of indicators that have the traits such as simplicity, ease of evaluation, use of the largest possible number of habitat (types of soil), highly sensitive to environmental changes, to soil and climate management and be measured by quantitative and/or qualitative methods (FRIEDMAN, 2001; SAVIOZZI et al., 2001).

In the literature there are some works in that biological indicators were used to assess the effect of agricultural practices on soil quality (ARAÚJO; MONTEIRO; ABARKELI, 2003; ARAÚJO; MONTEIRO, 2006; 2007; D'ANDREA et al., 2002; MOREIRA; MALAVOLTA, 2004; SANTOS et al., 2004; MELERO et al., 2006).

According to KENNANDDEY; STENBERG (1999), the use of microbial community of the soil as a quality indicator is due to the dynamic nature of soil microorganisms and to the fact that its activity reflects the joint influence of all the factors that regulate the organic matter degradation and the nutrients transformation.

Furthermore, the microorganisms play essential functions in the soil structuring processes, humus formation, nitrogen biological fixation, mycorrhizal associations, nutrients solubilization for the plants, pathogens reduction and plants' pests, persistent compounds degradation applied to the soil and other changes in the soil properties that affect the plant growth (KENNEDY; PAPENDICK, 1995; KENNEDY; SMITTH, 1995).

In this sense, it is highlighted the use of nematodes as dynamic indicators of environmental conditions due to reflecting changes in the successional stages of natural systems and in the managed agroecosystems (BONGERS, 1990; ETTEMA; BONGERS, 1993; FERRIS et al., 2001; YEATES; BONGERS, 1999; SCHLOTER et al., 2003). Nematodes belong to the animal kingdom, phylum Nematoda. They are usually microscopic organisms (EKSCHMITT et al., 2001), are sensitive to environmental factors and changes in their activity and distribution. These aspects are fundamental to assess changes in soil quality (BONGERS; FERRIS, 1999; EKSCHMITT et al., 2001; FERRIS et al., 2001; FISCUS; NEHER, 2002; GUPTA; YEATES, 1997; NEHER, 2000; RITZ; TRUDGILL, 1999; YEATES, 2003).

According to HEGER et al. (2012), the standards of soils monitoring and interpretation through soil quality indicators can be measured through physical, chemical and biological processes.

SPELLMAN; DRINAN (2001) point out that the characterization of an environmental system based on chemical parameters only provides information about the quality of the environment at the time of measurement, not being possible to measure the impact of the successional events of the ecosystem. Among the various indicators of soil quality, the use of information contained in the biological processes represents a powerful approach to assess and interpret the impact of natural or anthropogenic disorders in the soil ecosystems. Living organisms can provide information about the cumulative effects of environmental changes.

Thus, knowledge on the diversity of these organisms in natural soils and soils in use under different production systems can be a very useful tool to determine a sustainable agriculture.

Because there are only a few studies that report on the biodiversity of soil microbiota, this work aimed to make a 
brief review about the diversity of nematodes as biological indicators of soil quality in agroecosystems. Such information is fundamental, so more sustainable measures can be developed and used.

\section{IMPORTANCE OF SOIL NEMATODES IN AGROECOSYSTEMS}

Agroecosystems are generally characterized by periodic perturbations in the soil, such as the use of pesticides and fertilizers which hinder the natural succession. Each of these disorders has a specific effect, which can result in decreased diversity (TIMPER, 2014).

Soil management practices, such as no-tillage farming, crop rotation and organic matter addition, also alter the soil structure (KUSHWAHA et al., 2001; SIX et al., 2000) and strongly influence the faunal communities' abundance and diversity (BRIAR et al., 2007).

Due to the nematodes responding quickly to changes in food availability, it is possible, based on the analysis of trophic level, to measure the abundance and diversity of these organisms in the environment (DIEMONT; MARTIN, 2005). For example, studies performed by Leroy et al. (2007) showed that areas with maize production which received organic fertilizer and cattle dung for seven years had lower abundance of plant parasitic nematodes of genus Pratylenchus and a small number of species of the family Tylenchidae. In contrast, in this same area it was verified that the population of bacteriophage nematodes belonging to the family Rhabditidae was higher.

According to PORAZINSKA et al. (1999), nematodes belonging to the family Rhabditidae, as stringent colonizers, seem to be affected predominantly by sudden increases in food sources. However, nematodes of the genus Cephalobus, characterized for not being such strong colonizers, would respond more to a combination of factors such as abundance and types of food, effects of organic matter in the soil, temperature, moisture and natural characteristics of the soil.

PFOTZER; SCHULER (1997) and FORGE et al. (2003) showed that the organic compound application favors higher soil biological activity with increase of the number of protozoa bacteriophage nematodes, resulting in a significant volume of organic matter and release of nutrients available for the plants.

It must be taken into account that the effect of organic alterations in phytoparasite nematodes depends on the specific type of organic matter, the proportion of carbon and nitrogen sources, which and how many possible antagonist nematodes present in the organic fertilizer and the application period of organic compounds (BONGERS; FERRIS, 1999).

In the United States, the communities of nematodes in natural ecosystems and agroecosystems (areas in the crop rotations diagrams), were studied under different levels of anthropic intervention (FRECKMAN; ETTEMA, 1993). In natural systems, the highest values for richness of taxa and diversity were determined. Bacteriophage nematodes predominated in all areas, while the microphages prevailed in the native vegetation systems, and the parasitic nematodes were less abundance in the area of crops where organic farming was practiced.

GOULART; FERRAZ (2003) compared the trophic diversity of an area of native vegetation of the cerrado with an area originally from cerrado where perennial crop was established (guava tree Psidium guajava L.) and with a cerrado area which for years had been cultivated with annual crop (maize Zea mays $\mathrm{L}$.). The authors observed that the removal of native vegetation from the cerrado and the implementation of guava and maize cultivations influenced the communities of nematodes in the areas sampled, resulting in a reduction in the relative abundance of predators or omnivores and lower trophic diversity.

In Brazil, a study carried out by TORRES et al. (2006), in areas cultivated with melon plant in Braunas, Rio Grande do Norte State, presented low abundance of nematodes belonging to the family Dorylaimidae, common in annual crops areas, reflecting the high level of disorder caused by the long monoculture of cotton plant, previous to the melon cultivation. The high population levels of bacteriophages and phytoparasites in relation to other trophic groups found and the low abundance of predators confirm the type of exploitation of the area, annual cultivation. According to the same authors, the short period of fallow period which the areas were submitted in the off-season did not re-establish the nematofauna balance, which presented low levels of population of omnivores and predators.

According to GOMES et al. (2003), the population of Dorylaimidae in the community is sensitive to the cultural practices and can thus be used as an indicator of environmental disorder. A high percentage of Dorylaimidae (>25\%) represents little human intervention in the field, while low percentage, the contrary.

In the United States, the trophic diversity and maturity indices of soil communities were compared occurring in five areas of agricultural production performed on "conventional" systems with the use of chemical inputs, and "organic", without the use of chemical inputs (NEHER, 1999). The crops grown in the studied areas were cereals and vegetables, mainly. The ecological indexes used did not allow, in general, discrimination between the communities of nematodes from the two cultivation systems. In view of such verification, it is concluded that, contrary to what might be assumed, the soils under organic management should not be considered, necessarily, as suitable reference environments, not always being feasible to be used in studies that aim to evaluate the 
measurement compared of biological quality between the soils from different ecosystems.

PAVAO-ZUCKERMAN; COLEMAN (2007) evaluated the functional composition and the nematodes community structure associated with the use of the urban soil. These authors observed that the abundance of omnivorenematode-predators tends to decrease as the use of urban soils increases. In this context, NILES; FRECKMAN (1998) emphasize that omnivore-predator nematodes, such as the ones from the orders Dorylaimida and Mononchida, are associated with stable environments, in higher abundance in more established communities.

In the research performed by VAID et al. (2014) on the diversity of species of nematodes that live in the Poonch forest, in India, the authors found a higher richness and abundance of bacteriophages nematodes, belonging to the family Rhabditidae, followed by the orders Dorylaimida and Mononchida. This shows that at the Poonch forest, in the cities of Jammu and Kashmir, India, less environmental disorders occur in the region, since the organisms identified of the orders Dorylaimida and Mononchida may be more sensitive than other groups of nematodes to environmental changes and physicochemical conditions of the soil.

\section{NEMATODES AS INDICATORS OF SOIL QUALITY}

The nematodes are the most abundant organisms in the animal kingdom (BONGERS; BONGERS, 1998) living in various populations that constitute the communities. The diversity and structure of nematodes community can be influenced by several factors, having great importance to its association with food sources and with the soil microbiota.

Five groups of nematodes in the soil according to YEATES et al. (1993) are distinguished basically, namely: phytoparasite, phytophagous, or those that feed on vascular plants; fungivorous or mycrophages, those who have as a source of food hyphae of saprophytic fungi, piercing them with a small knife; bacteriophages, which have as food basis any Prokaryotic source; carnivores or predators, feeding on soil invertebrates (protists, rotifers and other nematodes); and omnivores, which feed on animal and vegetable source.

There are about 25,000 species of nematodes known. Out of these, $35 \%$ lives in the soil, and approximately $10 \%$ parasites plants, being able to infect all the parts. Estimates indicate that the phytoparasite nematodes are, on average, responsible for $13 \%$ of losses at the global level in agricultural systems. More than three billion of nematodes can exist in 0.4 ha of land, and, although many species occupy the first $30 \mathrm{~cm}$ of soil, some of them are more common at more elevated depths. Many species are important in agriculture, due to the damage caused to production, and others, of free life, exactly by its beneficial effect to agriculture (RITZINGER; FANCELLI, 2006).

According to TURCO; BLUME (1999), the operation of soil microorganisms can serve as a sensitive biological marker for the understanding of stability within a given system. This strategy is quite useful, since it eliminates the need to study all individuals from the biological community.

Several characteristics of soil nematodes make them good candidates as bioindicators of processes of an ecosystem. The nematodes have the most important attributes of a bioindicator in perspective (CAIRNS et al., 1993): abundance in virtually all the environments, diversity of life strategies and feeding habits (YEATES et al., 1993), short life cycles and relatively well defined sampling procedures.

Some factors may determine the nematodes community composition, for example, the exchanges in food chain in the soil (RITZINGER et al., 2010), the effects of soil acidity correction (RATY; HUHTA, 2003), recovery of disturbed areas (YEATES et al., 1991; ETTEMA; BONGERS, 1993), variation in plant density per area (McSORLEY; FREDERICK, 1996), the level of plant cover (FRECKMAN; HUANG, 1998) and the use and soil management (FRECKMAN; ETTEMA, 1993; NEHER, 1999).

In addition, the nematodes play an important role in nitrogen mineralization and through decomposition processes of organic matter, allow to identify reference systems (NEHER, 2001), due to variations in the nematofauna abundance and composition becoming an important tool to define the general conditions of the soil (YEATES et al., 1999).

In the soil, the nematodes live in the capillary water in direct contact with their microenvironment. They do not migrate rapidly from stressful circumstances and many species survive to dehydration, freezing or the stress of oxygen (although others are more sensitive). The community structure is indicative of conditions on the horizon of soil in which they dwell. The nematodes occupy strategic positions in photoreceptor chains of food, feeding on soil organisms and serving as food for many others (BONGERS; FERRIS, 1999).

Also the nematodes respond rapidly to disorder and to enrichment, the increasing microbial activity leads to changes in the proportion of bacterial feeders in a community (BONGERS; FERRIS, 1999).

The increase of bacteriophage nematodes, for example, is directly associated with the organic matter decomposition, by the intake of saprophytic microbes and a higher rate of organic matter decomposition (EKSCHMITT et al., 2001). Among the bacteriophages, the dominating taxonomic groups belong to families Cephalobidae, Rabditidae and Plectidae. The members of the family Cephalobidae are abundant in all types of soil, the Rabditidae ones respond quickly to growth in organic resources, and the Plectidae ones are found in greater number under stress conditions or soil degradation (YEATES, 2003). 
The populational dynamics of microbiophage nematodes (fungivorous and bacteriophages) tend to synchronize with those of microorganisms of which these nematodes feed on (MIKOLA, 1998). Thus, fungivorous and bacteriophage nematodes affect the fungi and bacteria activity, consequently also affecting the processes performed by these microorganisms. In several environmental conditions, the microbiophage nematodes contribute directly and indirectly to the organic matter decomposition process, even raising carbon mineralization rates (breathing) and other nutrients (BARDGETT; CHAN, 1999; FERRIS et al., 1998; MIKOLA; SETALA, 1998; CHEN; FERRIS, 1999; LAAKSO; SETALA, 1999).

It is estimated that almost $40 \%$ of the nutrients digestion is due to nematodes and other soil organisms that feed on microorganisms (YEATES, 2003). Studies performed by BEARE (1997) showed that the contribution of nematodes on nitrogen mineralization varies between 8 and 19\% in the conventional management systems and integrated pest management, respectively.

\section{MEASUREMENT OF THE NEMATODES COMMUNITIES}

The importance and the awareness of the nematodes use in the soil, as biodiversity and sustainability indicators, have been increasingly exploited (NEHER, 2001; YEATES, 2003; LIANG et al., 2009).

The main parameters studied in order to characterize the soil invertebrate communities are: species abundance and diversity (NAHMANI; LAVELLE, 2002; SATTLER et al., 2010). However, such parameters themselves do not explain the effects of pollution in the environment. Therefore, some ecological indexes have been proposed, as, for example, the maturity index (IM) (BONGERS, 1990), structural index (IS), enrichment index (IE) and channel index (IC) (FERRIS et al., 2001; FERRIS; MATUTE, 2003), diversity indices of Shannon-Weaver, of dominance of Simpson, of uniformity of Pielou (PARISI et al., 2005).

These indices facilitate the conceptual interpretation and analysis of the nematodes community compared to changes in the environment (KALKHORANA; AHANGARB, 2014). Furthermore, according to MONDINO et al. (2009), when the analyses are used in combination, they reveal descriptive and qualitative information on the soil nematode community and the conditions of the natural and/or agricultural systems conditions.

The maturity index (BONGERS, 1990) is used as an indicator of the ecological succession in which a community of nematodes is found and as a measure of the environment disorder. To obtain this index, "colonizers" are considered the nematodes that have rapid increase of population under favorable conditions, have a short life cycle, high capacity for colonization and increased tolerance to disorder or environmental disturbances. "Persistent" are those which have low reproductive rates and long life cycle, low capacity for colonization and higher sensitivity to the environment disturbances. Based on these characteristics, a scale of values was created from 1 to 5 , called c-p, being the closest to 1 related to colonizer nematodes and the ones closest to 5 the persistent nematodes.

The c-p values are used for determining the maturity index, which is calculated taking into account only the freeliving nematodes, and not the plants parasites. Low and high c-p weights will correspond to the relatively tolerant and sensitive rate to ecological disorder, respectively, and according to GOMES et al. (2003), low rates indicate a large number of colonizers (short life cycle, high reproductive rate and tolerance to environmental disorder), while high levels indicate a high degree of persistence in the population (long life cycle, low reproductive rate and sensitivity to environmental change). There is also an "index of plants parasites", which considers only the phytoparasite nematodes and is calculated in the same way (BONGERS, 1990).

According to FERRIS et al. (2001), the enrichment index (EI) indicates the response of the primary decomposer organisms to the available resources, whereas the structural index (SI) suggests the status of trophic chain affected by stress or disorder. The channel index (IC) is an indicator of fungal or bacterial decomposition path prevalent in the soil.

For the analysis of species diversity, the following are used: the index of Shannon-Weaver $\left(\mathrm{H}^{\prime}\right)$, which gives greater weight to the rare species; The Simpson index (Ds), which gives more weight to common species; and the index of uniformity of Pielou, which determines the equitable portion of diversity, how the individuals are distribute in the current rates (FERRIS et al., 2001).

At the agrarian ecosystems, the maturity index (MI) was used to differentiate between different soil preparation regimes. The frequency of the soil disorder is related inversely to the value of MI, but positively correlated with the plant parasite (PPI). The inverse relation between the PPI and the $\mathrm{MI}$ is apparent in its response to the applications of ammonia, fertilizers of nitrate and sewage water. The common factor in such studies is the soil enrichment. The enrichment stimulates microbial activity and subsequent succession, which is reflected within an initial decrease in MI followed by its gradual increase. The enrichment also increases the capacity to sustain nematodes that feed on plants, resulting in higher levels of PPI. The PPI, the MI and their ratio are valuable measures to assess the state of the agrarian ecosystems (BONGERS; FERRIS, 1999).

BONGERS et al. (1991) applied the MI for areas subject to different types of impacts (by oil, organic matter, heavy 
metal contamination, among others), and the results showed that the index was efficient to separate impacted and nonimpacted biotypes, as well as separate fresh water habitats from marine ones, as well as shallow water stations from deep waters. In impacted, MI presented low values when compared with the values obtained for areas with little or no impact.

According to KALKHORANA; AHANGAR (2014), biodiversity should not be seen only as a large number of species, but the life strategy of these species should be taken into account that make up the ecosystem. Recently, there is a growing consensus that the taxonomic diversity and nematodes functional communities is of crucial importance to determine changes in the ecosystem. However, there is no consistent pattern way to quantify the functional groups, which are the key to the diversity analysis.

\section{FINAL CONSIDERATIONS}

In this context, the favorable aspects to the use of nematodes as soil quality indicators in agroecosystem were analyzed. Several species of nematodes are sensitive to the environment variations, allowing serve as bioindicators.

The population of these organisms can vary according to agricultural practice adopted, being used for the characterization of systems in disorder. Furthermore, it is relevant to highlight the functions performed by such organisms in structuring the soil, through the movement of mineral and organic particles, and on the nutrients' cycling. Due to the great importance of soil microorganisms, with emphasis on the nematodes, it is necessary more incentives for research on the diversity of these organisms in the soil.

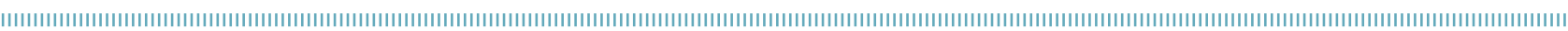
REFERENCES

ARAÚJO, A.S.F.; MONTEIRO, R.T.R. Indicadores biológicos de qualidade do solo. Bioscience Journal, Uberlândia, MG, v.23, p.66-67, 2007.

ARAÚJO, A.S.F.; MONTEIRO, R.T.R. Microbial biomass and activity in a Brazilian soil plus untreated and composted textile sludge. Chemosphere, Oxford, v.64, p.1043-1046, 2006.

ARAÚJO, A.S.F.; MONTEIRO, R.T.R.; ABARKELI, R.B. Effect of glyphosate on the microbial activity of two Brazilian soils. Chemosphere, Oxford, v.52, p.799-804, 2003.

BARDGETT, R.D.; CHAN, K.F. Experimental evidence that soil fauna enhance nutrient mineralization and plant nutrient uptake in montage grassland ecosystems. Soil Biology and Biovhemistry, v.31, n.7, p.1007-1014, 1999.

BEARE, M.H. Fungal and bacterial pathways of organic matter decomposition and nitrogen mineralization in arable soil. In: BRUSSARD, L.; FERRERA CERRATO (Ed.). Soil ecology in sustainable agricultural systems. Boca Raton: CRC, 1997. p.33-70.

BENINTENDE, S.; BENINTENDE, M.; STERREN, M.; DE BATTISTA, $J$. Soil microbial indicators of soil quality in four rice rotation systems. Ecological Indicators, v.8, p.704-708, 2008.

BONGERS, T.; ALKEMADE, R.; YEATES, G.W. Interpretation of disturbance-induced maturity decrease in marine nematode assemblages by means of the Maturity index. Marine Ecology Progress Series, v.76, p.135-142, 1991.

BONGERS, T.; BONGERS, M. Functional diversity of nematodes. Applied Soil Ecology, v.10, p.239-251, 1998.

BONGERS, T.; FERRIS, H. Nematode community structure as a bioindicator in environmental monitoring. Trends in Ecology \& Evolution, v.14, n.6, p.224-228, 1999.
BONGERS, T. The maturity index: an ecological measure of environmental disturbance based on nematode species composition. Oecologica, v.83, p.14-19, 1990.

BRIAR, S.S.; GREWAL, P.S.; SOMASEKHAR, N.; STINNER, D.; MILLER, S.A. Soil nematode community, organic matter, microbial biomass and nitrogen dynamics in field plots transitioning from conventional to organic management. Applied Soil Ecology, v.37, p.256-266, 2007.

CAIRNS JR., J.; MCCORMICK, P.V.; NIEDERLEHNER, B.R. A proposed framework for developing indicators of the ecosystem health. Hydrobiologia, v.263, n.1, p.44, 1993.

CHEN, J.; FERRIS, H. Effects of nematode grazing on nitrogen mineralization during fungal decomposition of organic matter. Soil Biology and Biochemistry, v.31, n.9, p.1265-1279, 1999.

D'ANDREA, A.F.D.; SILVA, M.L.N.; CURI, N.; SIQUEIRA, J.O.; CARNEIRO, M.A.C. Atributos biológicos indicadores da qualidade do solo em sistemas de manejo na região do cerrado no sul do estado de Goiás. Revista Brasileira de Ciência do Solo, Viçosa, v.26, p.913-923, 2002.

DIEMONT, S.A.W.; MARTIN, J.F. Management impacts on the trophic diversity of nematode communities in an indigenous agroforestry system of Chiapas, Mexico. Pedobiologia, v.49, p.325-334, 2005.

ETTEMA, C.H.; BONGERS, T. Characterization of nematode colonization and succession in disturbed soil using the maturity index. Biology and. Fertility of Soils, v. 16, p.79-85, 1993.

EKSCHMITT, K.; BAKONYI, G.; BONGERS, M.; BONGERS, T.; BOSTRÖM, S.; DOGAN, H.; HARRISON, A; NAGY, P.; O'DONNELL, A.G.; PAPATHEODOROU, E.M.; SOHLENIUS, B.; STAMOU, G.P.; WOLTERS, V. Nematode community structure as indicator of soil functioning in European grassland soils. European. Journal. Soil Biology, v.37, p.263-268, 2001. 
FERRIS, H.; BONGERS, T.; DE GOEDE, R.G.M. A framework for soil food web diagnostics: extension of the nematode faunal analysis concept. Applied Soil Ecology, v. 18, p.13-29, 2001.

FERRIS, H.; MATUTE, M.M. Structural and functional succession in the nematode fauna of a soil food web. Applied Soil Ecology, v.23, p.93-110, 2003.

FERRIS, H.; VENETTE, R.C.; VAN DER MEULEN, H.R.; LAU, S.S. Nitrogen mineralization by bacterial-feeding nematodes: verification and measurement. Plant and Soil, v.203, n.2, p.159$171,1998$.

FISCUS, D.A; NEHER, D.A. Distinguishing sensitivity of free-living soil nematode genera to physical and chemical disturbances. Ecology Applied, v. 12, p.565-575, 2002.

FORGE, T.A.; HOGUE, E.; NEILSEN, G.; NEILSEN, D. Effects of organic mulches on soil microflora in the root zone of apple: implications for nutrient fluxes and functional diversity of the soil food web. Applied Soil Ecology, v.22, p.39-54, 2003.

FRECKMAN, D.W; ETTEMA, C.H. Assessing nematode communities in agroecosystems of varying human intervention. Agriculture, Ecosystems and Environment, v.45, p.39-261, 1993.

FRECKMAN, D.W; HUANG, S.P. Response of the soil nematode community in a shortgrass steppe to long-term and short-term grazing. Applied Soil Ecology, v.9, p.39-44, 1998.

FRIEDMAN, D.; HUBBS, M.; TUGEL, A.; SEYBOLD, C.; SUCIK, M. Guidelines for soil quality assessment in conservation planning. United State Departament of Agriculture. NRCS/Soil Quality Institute. 38 p. 2001.

GOMES, G.S.; HUANG, S.P.; CARES, J.E. Nematode community, trophic structure and population fluctuation in soybean fields. Fitopatologia Brasileira, v.28, p.258-266, 2003.

GOULART, A.M.; FERRAZ, L.C.C.B. Comunidades de nematóides em Cerrado com Vegetação Original Preservada ou Substituída por Culturas. Nematologia Brasileira, v.27, n.2, p.123-128, 2003.

GUPTA, V.V.S.R.; YEATES, G.W. Soil microfauna as bioindicators of soil health. In: PANKHURST, C.E.; DOUBE, B.M.; GUPTA, V.V.S.R. (Eds.). Biological Indicators of Soil Health. CABI Publishing, Wallingford, UK, p. 201-233, 1997.

HEGER, T.J.; IMFELD, G.; MITCHELL, E.A.D. Special issue on "Bioindication in soil ecosystems": Editorial note. European Journal of Soil Biology, v.49, p. 1-4, 2012.

KARLEN, D.L.; ANDREWS, S.S.; DORAN, J.W. Soil quality current concepts and applications. Advances in Agronomy, v.74, p. 1-40, 2001.

KARLEN, D.L.; ANDREWS, S.S.; WIENHOLD, B.J.; DORAN, J.W. Soil quality: Humankind's foundation for survival. Journal of Soil and Water Conservation, Ankeny, v.58, n.4, p.171-179, Jul./Aug. 2003.

KASCHUK, G.; ALBERTON, O.; HUNGRIA, M. Quantifying effects of different agricultural land uses on soil microbial biomass and activity in Brazilian biomes: inferences to improve soil quality. Plant Soil, v.338, p.467-481, 2011.
KENNEDY, A.C.; PAPENDICK, R.I. Microbial characteristics of soil quality. Journal Soil Water Conservation, v.50, p.243-248, 1995.

KENNEDY, A.C.; SMITH, K.L. Soil microbial diversity and the sustainability of agricultural soils. Plant and Soil, The Hague, v.170, n.1, p.75-86, 1995.

KUSHWAHA, C.P.; TRIPATHI, S.K.; SINGH, K.P. Soil organic matter and water-stable aggregates under different tillage and residue conditions in a tropical dry land agroecosystem. Applied Soil Ecology, v.16, n.3, p.229-241, 2001;

KALKHORANA, S.S.; AHANGAR, A.G. Nematode as a soil biodiversity indicator. Agricultural Advances, v.3, n.3, p.67-73, 2014.

LAAKSO, J.; SETALA, H. Population and ecosystem level effects of predation on microbial feeding nematodes. Oceologia, v.120, n.2, p.279-286, 1999.

LEROY, B.L.M.M.; BOMMELE, L.; REHEUL, D.; MOENS, M.; DE NEVE, $\mathrm{S}$. The application of vegetable, fruit and garden waste (VFG) compost in addition to cattle slurry in a silage maize monoculture: Effects on soil fauna and yield. European Journal of Soil Biology, v.43, p.91-100, 2007.

LIANG, W.; LOU, Y.; LI, Q.; ZHONG, S.; ZHANG, X.; WANG, J. Nematode faunal response to long-term application of nitrogen fertilizer and organic manure in Northeast China. Soil Biology \& Biochemistry, v.41, p.883-890, 2009.

MIKOLA, J.; SETALA, H. No evidence of trophic cascades in an experimental microbial based soil food web. Ecology, v.79, n.1, p. 153-164, 1998.

MIKOLA, J. Effect of microbivore species composition and basal resource enrichment on trophic level biomasses in an experimental microbial based soil food web. Oceologia, v.117, n. 3, p. 396-403, 1998.

MCSORLEY, R.; FREDERICK, J.J. Nematode community structure in rows and between rows of a soybean field. Fundamental and Applied Nematology, v. 19, n.3, p.251-261, 1996.

MELERO, S.; PORRAS, J.C.R.; HERENCIA, J.F.; MADEJON, E. Chemical and biochemical properties in a silty loam soil under conventional and organic management. Soiland Tillage Research, Londres, v.90, p.162-170, 2006.

MONDINO, E.A.; TAVARES, H.O.C.; EBELING, A.G.; FIGUEIRA, A.F.; QUINTERO, E.I.; BERBARA, R.L.L. Avaliação das comunidades de nematoides do solo em agroecossistemas orgânicos. Acta Scientiarum. Agronomy, v.31, n.3, p.509-515, 2009.

MOREIRA, A.; MALAVOLTA, E. Dinâmica da matéria orgânica e da biomassa microbiana em solo submetido a diferentes sistemas de manejo na Amazônia Ocidental. Pesquisa Agropecuária Brasileira, Brasília, v.39, p.1103-1110, 2004.

NAHMANI, J.; LAVELLE, P. Effects of heavy metal pollution on soil macrofauna in a grassland of Northern France. European Journal of Soil Biology, v.38, p.297-300, 2002.

NEHER, D.A. Role of nematodes in soil health and their use as indicators. In: 39th Annual Meeting of the Society of Nematologists, Quebec City, Canada, 2000. 
NEHER, D.A. Nematode communities in organically and conventionally managed agricultural soil. Journal of Nematology, v.31, p.42-154, 1999.

NEHER, D.A. Role of nematode in soil health and their use as indicator. Journal of Nematology, v. 33, n.4, p.161-168. 2001.

NILES, R.K.; FRECKMAN, D.W. from the ground up: nematode ecology in bioassessment and ecosystem heath. In: BARTELS, J.M. (Ed.). Plant and nematode interactions. Madison: ASA: CSSA: SSSA, 1998, cap. 4. p.65-85.

PARISI, V.; MENTA, C.; GARDI, C.; JACOMINI, C.; MOZZANICA, E. Microarthropod communities as a tool to assess soil quality and biodiversity: a new approach in Italy. Agriculture Ecosystem and Environment, v.105, p.323-333, 2005.

PAVAO-ZUCKERMAN, M.A.; COLEMAN, D.C. Urbanization alters the functional composition, but not taxonomic diversity, of the soil nematode community. Applied Soil Ecology, v.35, p.329-339, 2007.

PFOTZER, G.H.; SCHULER, C. Effects of different compost amendments on soil biotic and faunal feeding activity in an organic farming system. Biological Agriculture and Horticulture, v. 15, p.177-183, 1997.

PORAZINSKA, D.L.; DUNCAN, L.W.; MCSORLEY, R.; GRAHAM, J.H. Nematode communities as indicator of status and processes of a soil ecosystem influenced by agricultural management practices. Applied Soil Ecology, v.13, p.69-86, 1999.

RATY, M.; HUHTA, V. Nematode communities of anthropogenous birch stands in central Finland. Nematology, Leiden, v.5, n.4, p.629-639, 2003.

RITZ, K.; TRUDGILL, D.L. Utility of nematode community analysis as an integrated measure of the functional state of soils: perspectives and challenges. Plant Soil, v.212, p.1-11, 1999.

RITZINGER, C.H.S.P; FANCELLI, M. Integrated management of nematodes in the banana tree culture. Revista Brasileira de Fruticultura, Jaboticabal, v.28, n.2, 2006.

RITZINGER, C.H.S.P.; FANCELLI, M.; RITZINGER, R. Nematodes: Bioindicator of sustainability and edaphoclimatic changes. Revista Brasileira de Fruticultura, v.32, n.4, p.1289-1296, 2010.

ROVEDDER, A.P.; ANTONIOLLI, Z.I.; SPAGNOLLO, E.; VENTURINI, S. Fauna edáfica em solo susceptível à arenização na região sudoeste do Rio Grande do Sul. Revista de Ciências Agroveterinárias, Lages, v.3, n.2, p.87-96, 2004.

SANTOS, V.B.; CASTILHOS, D.D.; CASTILHOS, R.M.V.; PAULETTO, E.A.; GOMES, A.S.; SILVA, D.G. da. Biomassa, atividade microbiana e teores de carbono e nitrogênio totais de um plano solo sob diferentes sistemas de manejo. Revista Brasileira de Agrociência, Pelotas, v.10, p.333-338, 2004

SATTLER, T.; DUELLI, P.; OBRIST, M.K.; ARLETTAZ, R.; MORETTI, $M$. Response of arthropod species richness and functional groups to urban habitat structure and management. Landscape Ecology, v. 25, p. 941-954, 2010.

SIX, J.; ELLIOTT, E.T.; PAUSTIAN, K. Soil macroaggregate turnover and microaggregate formation: a mechanism for $C$ sequestration under no-tillage agriculture. Soil Biology and Biochemistry, v.32, p.2099-2103, 2000.

SCHOWNHOLTZ, S.H.; VAN MIEGROET, H.; BURGER, J.A. A review of chemical and physical properties as indicators of forest soil quality: challenges and opportunities. Forest Ecology and Management, Amsterdam, v.138, n. 1, p.335-356, 2000.

SCHLOTER, M.; DILLY, O.; MUNCH, J.C. Indicators for evaluating soil quality. Agriculture, Ecosystems and Environment, v.98, p.255-262, 2003.

SPELLMAN, F.R.; DRINAN, J.E. Stream Ecology and Self-purification: An Introduction. $2^{\mathrm{a}}$ ed. Taylor and Francis, Pennsylvania, USA, 2001. $261 \mathrm{p}$.

STENBERG, B. Monitoring soil quality of arable land: microbiological indicators. Soil Plant Science, v.49, p.1-24, 1999.

TIMPER, P. Conserving and Enhancing Biological Control of Nematodes. Journal of Nematology, v.46, n.2, p.75-89, 2014.

TORRES, G.R.C.; PEDROSA, E.M.R.; MONTENEGRO, A.A.A.; MICHEREFF, S.J.; MOURA, R.M.. Aspectos ecológicos da comunidade de nematóides associada ao cultivo de Cucumismelo no Rio Grande do Norte. Nematologia Brasileira, v.30, n. 1, p. 1-9, 2006.

TURCO, R.F.; BLUME, E. Indicators of soil quality. In: SIQUEIRA, J.O.; MOREIRA, F.M.S.; LOPES, A.S.; GUILHERME, L.G.R.; FAQUIN, V.; FURTINI NETO, A.E.; CARVALHO, J.G. (Orgs.). Inter-relação fertilidade, biologia do solo e nutrição de plantas. Viçosa: SBCS; Lavras: UFLA/DCS, 1999. p.529-549.

VAID, S.; SHAH, A.A.; AHMAD, R.; HUSSAIN, A. Diversity of soil inhabiting nematodes in Dera Ki Gali forest of Poonch district, Jammu and Kashmir, India. International Journal of Nematology, v.24, n. 1, p.97-102, 2014.

WEIL, R.R.; MAGDOFF, F. Significance of soil organic matter to soil quality and health. In: WEIL, R.R.; MAGDOFF, F. (Eds.). Soil Organic Matter in Sustainable Agriculture. Florida: CRC Press, 2004. p.1-43.

YEATES, G.W. Nematodes as soil indicators: functional and biodiversity aspects. Biolology and Fertility of Soils, v.37, p. 199-210, 2003.

YEATES, G.W.; BONGERS, T.; GOEDE, R.G.M.; FRECKMAN, D.W.; GEORGIEVA, S.S. Feeding habits in nematode families and generaan outline for soil ecologists. Journal of Nematology, v.25, n.3, p.315-331, 1993.

YEATES, G.W.; BAMFORTH, S.S.; ROSS, D.J.; TATE, K.R.; SPARLING, G. Recolonization of methyl bromide sterilized soil under four different field conditions. Biology and Fertility of Soils, v. 11 , p.181-189, 1991.

YEATES, G.W.; BONGERS, T. Nematode diversity in agroecosystems. Agriculture Ecosystems Environment, v.74, p.113-135, 1999.

YEATES, G.W.; WARDLE, D.A.; WATSON, R.N. Responses of soil nematode populations, community structure, diversity and temporal variability to agricultural intensification over a seven-year period. Soil Biology and Biochemistry, v.31, p.1721-1733, 1999. 